\section{Commentary: Fontan circulation with lymphatic failure: Was the Holy Grail finally found?}

\author{
Eugen Sandica, MD
}

Fontan himself noted that "the Fontan operation creates an unusual state...it is the Fontan state itself and the transition (by surgery) from a state of congenital heart disease to the Fontan state that constitutes the risk and makes the operation palliative and not curative."1 The Fontan state induces physiologic changes as a consequence of the missing subpulmonary ventricle. It was very clear for Fontan 30 years ago that "the Fontan state...imposes a gradually declining functional capacity and premature late death after an initial period of often excellent palliation." ${ }^{1}$ Since then, important progress has been made in surgical and medical management, while at the same time the population of patients living with Fontan physiology also changed. Today, hypoplastic left heart syndrome is the most common underlying diagnosis, and it is known that these patients are more likely to develop Fontan failure. ${ }^{2}$

With the increasing number of patients who are palliated with Fontan operations worldwide, the number of patients with failing Fontan is also increasing. Pediatric and adult cardiologists, as well as congenital heart surgeons are facing a new challenge: management of the Fontan circulation with its different categories of failure, including ventricular dysfunction, Fontan circuit failure, lymphatic failure, and extracardiac organ failure. ${ }^{3}$ Although favorable results can be achieved after heart transplantation, the subsets of patients with preserved ventricular function have a much higher mortality. ${ }^{4,5}$

\footnotetext{
From the Department of Surgery for Congenital Heart Defects, Heart and Diabetes Center NRW, Bad Oeynhausen, Germany.

Disclosures: The author reported no conflicts of interest.

The Journal policy requires editors and reviewers to disclose conflicts of interest and to decline handling or reviewing manuscripts for which they may have a conflict of interest. The editors and reviewers of this article have no conflicts of interest.

Received for publication Jan 31, 2021; revisions received Jan 31, 2021; accepted for publication Feb 1, 2021; available ahead of print Feb 3, 2021.

Address for reprints: Eugen Sandica, MD, Department of Surgery for Congenital Heart Defects, Heart and Diabetes Center NRW, Georgstrasse 11, 32545 Bad Oeynhausen, Germany (E-mail: esandica@hdz-nrw.de).

JTCVS Techniques 2021;7:263-4

2666-2507

Copyright (C) 2021 The Authors. Published by Elsevier Inc. on behalf of The American Association for Thoracic Surgery. This is an open access article under the CC BY-NCND license (http://creativecommons.org/licenses/by-nc-nd/4.0/).

https://doi.org/10.1016/j.xjtc.2021.02.002
}

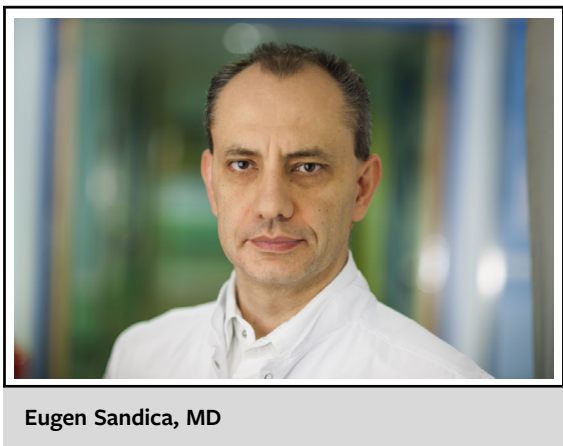

CENTRAL MESSAGE

The innominate vein turndown procedure seems to be effective

in Fontan circulation with

lymphatic failure and should be considered as an option, at least in critical cases.

The innominate vein turndown procedure was introduced to manage the lymphatic failure by decompressing the thoracic duct with concomitant increase of preload. ${ }^{6}$ In their article in this issue of the Journal, Hraška and colleagues ${ }^{7}$ describe the progress that has been made in the diagnosis of lymphatic failure using magnetic resonance imaging, the selective lymphatic embolization that has been successfully used to treat plastic bronchitis, and the refined modifications of the original surgical procedure (interposition of a ring-reinforced polytetrafluoroethylene graft to connect the innominate vein to the atrium using a dunk technique in case of a short innominate vein and banding of the jugular vein in case of desaturation below $80 \%$ after the procedure). The authors report 1 early death and 3 late deaths in 14 patients. The median follow-up was 19 months (interquartile range, 0 to 36 months). All survivors showed improvement of the Fontan state, with most having no protein-losing enteropathy, plastic bronchitis, ascites, or effusions. This is indeed remarkable, considering that this procedure was performed as "last resort" therapy.

Management of Fontan patients with lymphatic failure remains a challenge. The innominate vein turndown procedure seems to be effective and should be considered at least in critical cases. Performing this procedure at the time of the Fontan operation could be an attractive strategy in selected patients, in an attempt to delay the failure of Fontan physiology. Long-term results in more patients hopefully will provide the answer. 


\section{References}

1. Fontan F, Kirklin JW, Fernandez G, Costa F, Naftel DC, Tritto F, et al. Outcome after a "perfect" Fontan operation. Circulation. 1990;81: 1520-36.

2. Iyengar AJ, Winlaw DS, Galati JC, Wheaton GR, Gentles TL, Grigg LE, et al. The extracardiac conduit Fontan procedure in Australia and New Zealand: hypoplastic left heart syndrome predicts worse early and late outcomes. Eur J Cardiothorac Surg. 2014;46:465-73.

3. McCormick AD, Schumacher KR. Transplantation of the failing Fontan. Transt Pediatr. 2019;8:290-301.
4. Griffiths ER, Kaza AK, Wyler von Ballmoos MC, Loyola H, Valente AM, Blume ED, et al. Evaluating failing Fontans for heart transplantation: predictors of death. Ann Thorac Surg. 2009;88:558-64.

5. Murtuza B, Hermuzi A, Crossland DS, Parry G, Lord S, Hudson M, et al. Impact of mode of failure and end-organ dysfunction on the survival of adult Fontan patients undergoing cardiac transplantation. Eur J Cardiothorac Surg. 2017;51:135-41.

6. Hraška V. Decompression of thoracic duct: new approach for the treatment of failing Fontan. Ann Thorac Surg. 2013;96:709-11.

7. Hraška V, Hjortdal VE, Dori Y, Kreutzer C. Innominate vein turn-down procedure: killing two birds with one stone. J Thorac Cardiovasc Surg Tech. 2021;7:253-60. 